\title{
Fresh- and therapeutic groundwater mixing model in Tylicz region (Polish Carpathians)
} University of Wroclaw, Institute of Geological Sciences, pl. M. Borna 9, 50-204 Wrocław, Poland; *Corresponding author,
E-mail: marek.wcislo@uwr.edu.pl

(Received: May 27, 2019; Revised accepted: November 5, 2019)

https://doi.org/10.18814/epiiugs/2019/019024

The fresh and therapeutic waters near Tylicz have been exploited for nearly 200 years and have come to play a crucial role in the region's economic development. Their chemical composition results from the mixing of (shallow) freshwater with therapeutic water found at depths of 100-200 m. In tectonic environments, both types of water become saturated with carbon dioxide. The overexploitation of either type of water can lead to changes in the way the water mixes and result in the alteration of its physical and chemical properties. The paper presents hydrodynamic model of water mixing drained by wells, basing on the composition and discharge of the waters. The model comprises seven layers to a depth of $900 \mathrm{~m}$ and accurately reflects the complex structure of the flysch facies. The well P-1 catchment was subjected to detailed analysis: here the changes in mineralization triggered by altered water are most visible and well-documented. Contrary to initial claims, the results seem to indicate that the exploitation of adjacent freshwater and therapeutic wells does not necessarily have any impact on the waters' chemical composition. It has, however, been proved that the composition of therapeutic water is strongly influenced by therapeutic water discharge.

\section{Introduction}

Understanding processes of interaction between therapeutic (therapeutic water was named mineral water with healing properties) and fresh groundwater in aquifer is very important because it can affect the strategy of extraction and protection of water resources against over-exploitation. This problem concerns, among others the Poprad Valley (southern Poland, the Carpathians), where over the past 200 years several local health and bottling industry hubs have evolved (Hacquets, 1796; Zejszner, 1836), in towns such as Muszyna, Krynica Zdrój and Tylicz (Fig. 1). The entire Polish section of the Poprad Valley is referred to as a the 'mineral water bottling basin'(Rajchel, 2012), since it is home to approximately 14 bottling stations and 6 health resorts, which make use of catchments with a joint yield of 220 $\mathrm{m}^{3} / \mathrm{h}$ (Felter et al., 2015). On the hydrogeological map of Poland, this area has been designated as a separate entity (Dowgiałło and Paczyński, 2002), whose distinguishing feature is the presence of specific therapeutic waters known as acidulous waters (containing no less than $1,000 \mathrm{mg} / \mathrm{dm}^{3}$ of free $\mathrm{CO}_{2}$ ) and waters whose $\mathrm{CO}_{2}$ content falls between $250-1,000 \mathrm{mg} / \mathrm{dm}^{3}$ (Buczyński et al., 2017). Owing to their specific properties and the rarity with which they occur, therapeutic waters are under strict protection (Ciężkowski et al., 2010) and their exploitation is regulated by law. This entails classifying therapeutic, thermal and brine waters as mineral resources and defining extraction areas for each of them. The protection of these resources is implemented through avoiding the exploitation of freshwater in areas where it occurs alongside therapeutic waters (Ciężkowski, 2007). Isotope research indicates that the carbonated water or $\mathrm{CO}_{2}$ rich water found in the Carpathians date back to the Holocene and glacial periods, and as a result of mixing processes comprise a mix of dehydration waters and contemporary infiltration waters (Rajchel, 2012). It also appears that the aquifer system is highly sensitive to changes in the exploitation levels and recharge conditions (Nowicki and Felter, 2013). In particular, these changes will affect the waters' mixing ratio and as such disrupt the chemical composition and dynamics of groundwater reserves. In the area under study, the bottling industry relies partly on fresh water, which is why research into the effects of its exploitation on therapeutic waters is so essential.

Sources assume varying standpoints regarding the contribution of freshwater exploitation to the disruption of the mixing ratio between fresh and therapeutic waters. Studies have shown that therapeutic waters occurring naturally in south-western Poland (e.g., in Lądek Zdrój) exhibit notable variations in discharge following the establishment of new wells (Ciężkowski, 2007). In the Carpathians, variations in the concentration of carbon dioxide and the decline in mineralization of acidulous waters have been associated mainly with earth moving and mining activities or malfunctions in the water supply system around the towns of Piwniczna, Krynica Zdrój and Szczawnica (Rajchel, 2012). In a small number of wells near Tylicz, mineralization levels exhibit considerable multi-annual variation, which cannot always be attributed to exploitation, although in some cases there appears to be a clear connection. Despite these inconsistencies, the exploitation of new freshwater catchments in areas where therapeutic waters occur is prohibited.

The regional groundwater model created for the purposes of this research covers $70.4 \mathrm{~km}^{2}$ and includes the drainage basin of the upper 


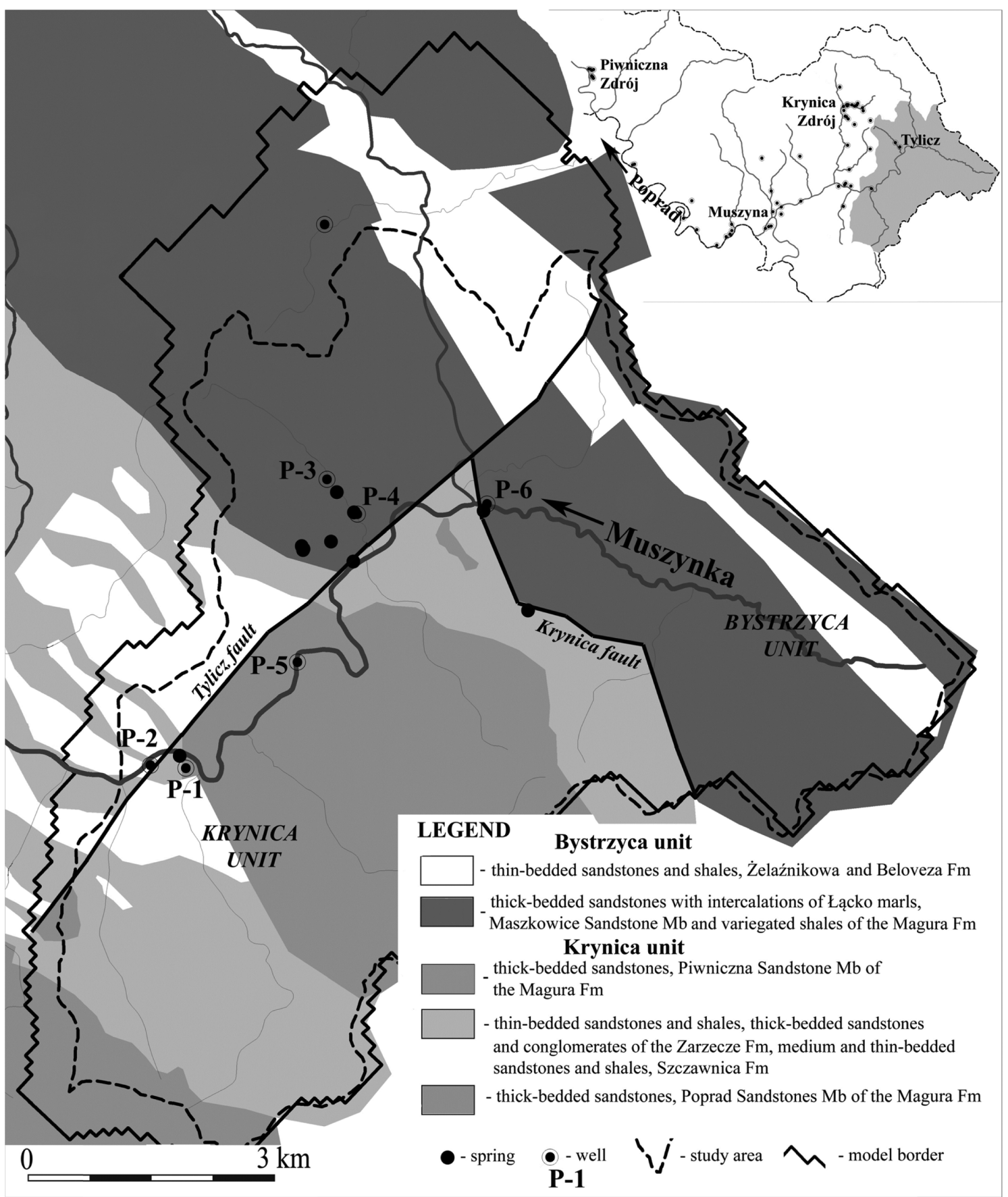

Figure 1. Study area.

river Muszynka $\left(53.2 \mathrm{~km}^{2}\right)$ and was intended to illustrate the way fresh and therapeutic waters mix, and to enable the assessment of the way their catchments influence each other. It also served to evaluate therapeutic water reserves and to determine whether adjacent therapeutic and fresh water catchments can be safely exploited. The advantage of suggested method (in comparison to chemical and isotopic analysis) is possibility to generate prognoses, which show the steadystate (final) composition of water by known discharge. Also the effects of the increased therapeutic water exploitation on the mixing ratio between these and fresh waters were studied, and the results of model research were compared with results obtained using the Ovczynnikov method. Due to the volume limited of the paper, detailed test results based on the one year $\mathrm{H}, \mathrm{O}$, and $\mathrm{S}$ isotope and chemical observations (hydrogeochemical mixing model) described in Buczyński et al., (2015), Staśko and Modelska (2016).

\section{Research Area}

\section{Location and Climate}

Hydrogeological model was constructed to simulate Muszynka river drainage basin to the hydrological profile in Powroźnik (area of $53.2 \mathrm{~km}^{2}$ ), located in South Poland (Fig. 1), in Outer Western Car- 
pathians. Owing to its river network and the specific drainage pattern, the region exhibits significant morphological variation $(509-894 \mathrm{~m}$ above sea level). The average annual temperature ranges from 4 to $6{ }^{\circ} \mathrm{C}$. Average year-long precipitation levels fall between $849 \mathrm{~mm}$ at the station in Krynica Zdrój (Institute of Meteorology and Water Management) and $862 \mathrm{~mm}$ at the station in Tylicz (Multivita database). In the drainage basin of the upper river Muszynka, seven wells are used to extract fresh water, while the exploitation of therapeutic water is restricted to only three such sites. The total available resources of therapeutic water are $12.4 \mathrm{~m}^{3} / \mathrm{h}$. For fresh water this value is several times higher.

\section{Geology and Hydrogeology}

The research area is a part of Carpathy Mts (Polish outer Carpathian), composed of flysh (sandy-clayey layered sediments) - product of deep sea sedimentation, which is divided into units, depending of tectonic, faults and facial diversity. The area, where the model is constructed, can be divided in two main tecto-facial units: Bystrzyca unit and Krynica unit. The mentioned main units are divided into several formations, separated by sedimentary or tectonic barriers. The geological profile consist of sediments from the middle to late Eocene epoch. The Bystrzyca unit includes mainly shales and next - sandstones, and occasionally marbles. In this unit Beloveza Formation and shales of Magurska Formation can be distinguished. The Krynicka unit is dominated by sandstone and includes such formation as: Zarzecze Fm, Piwniczna Fm, Szczawnica Fm and Magura Fm. Two main tectonic zones extend over this area: Tylicz fault and Krynica fault. The morphology and surface water are strictly connected with main direction of this deformation (NE-SW and NW-SE). Numerous dislocation and fractures gives a preferential condition for $\mathrm{CO}_{2}$ migration from deeper part of lithosphere (Birkenmajer, 1986; Birkenmajer and Dudziak, 1988; Birkenmajer and Oszczypko, 1989; Oszczypko, 1991, 1998; Oszczypko et al., 1999).

According to the regionalization of fresh water by Paczyński (1995), the research area is part of the Carpathian hydrogeological region, where groundwater resources can be found mostly in flysch formations and less - in quaternary sediments of valleys. The thickness of quaternary deposits of the Muszynka's drainage basin is limited to $15 \mathrm{~m}$ and creates a local source of groundwater (Szczepański and Szklarczyk, 2005). More perspective resources occur within Neogene flysch. Flysch rocks do not exhibit typical aquifer formations; the presence of water resources is associated with sub-surface fissures and weathered rocks (often of varying ages). As previous research shows, the lowest border of circulation and fresh groundwater exchange reaches depths of 60-80 m, depending on the rock type and morphology (Chowaniec, 2006), or up to $100 \mathrm{~m}$ (Witczak et al., 2002). The amount of water retained in the flysch rocks is determined by the shape and porosity of sandstone units. More water-bearing are coarse-grain sandstones than mudstones and sandstones with mud cement. Extensive studies have shown that the effective porosity of sandstones from Bystrzycka unit and Krynicka subunit is low (1-10\%), while the storage coefficient fluctuates between $1.06 \times 10^{-4}-1.06 \times 10^{-5}$ (Krawczyk, 2010a, b). Tectonic and weathering processes result in development of cracks and fissures, building secondary porosity and permeability. Despite the rate of water exchange decrease with depth, the pressure distribution is under influence of morphology even up to depth of 1,500 m (Witczak et al., 2002; Zuber and Chowaniec, 2009). The hydraulic conductivity from pumping tests of the fractured- porous medium varies between $1.13 \times 10^{-4}$ and $1.25 \times 10^{-9} \mathrm{~m} / \mathrm{s}$ (Nałęcki et al., 2004). Jetel (1986), after analyzing the results of pumping tests, proposed the formula describing the relationship between the hydraulic conductivity and depth:

$$
\mathrm{K}_{\mathrm{H}}=\mathrm{K}_{0} \mathrm{e}^{-\mathrm{aH}}
$$

where $\mathrm{K}_{\mathrm{H}}$ - hydraulic conductivity at the depth of $\mathrm{H}[\mathrm{m} / \mathrm{s}]$;

$\mathrm{K}_{0}$-hydraulic conductivity of the near the surface sediments $[\mathrm{m} / \mathrm{s}]$; a-empirical coefficient

\section{Genesis and Occurrence of Therapeutic Waters}

Carbon dioxide-containing waters as well as acidulous waters occurring in the area under study are either contemporary or glacial, and diagenetic in origin. They are found predominantly in river valleys. The genesis of the endogenous carbon dioxide current remains a point of contention, although the theory suggesting the involvement of a number of different sources and processes (igneous, metamorphic and diagenetic) is nowadays the most widely accepted. Rajchel (2012) recapitulates these theories and concludes that the carbon dioxide originates in the subduction zone. In the area under study, many dry $\mathrm{CO}_{2}$ exhalations have been observed, apparently unrelated to therapeutic water reserves.

Based on the hydrogeological model created for the purposes of evaluating therapeutic water reserves, Kania et al. (2009) draw the conclusion that deep circulation within the regional flow system is essential for the creation of therapeutic mineral water, while waters taking part in the regional flow system (between $100 \mathrm{~m}$ and $200 \mathrm{~m}$ below ground level) may be identified with disposable resources of therapeutic water. Therefore, acidulous waters do not necessarily have to be old, since both contemporary infiltration waters and their blend with deep circulation waters can become saturated with $\mathrm{CO}_{2}$. This is shown in Fig. 2 (Rajchel 2012).

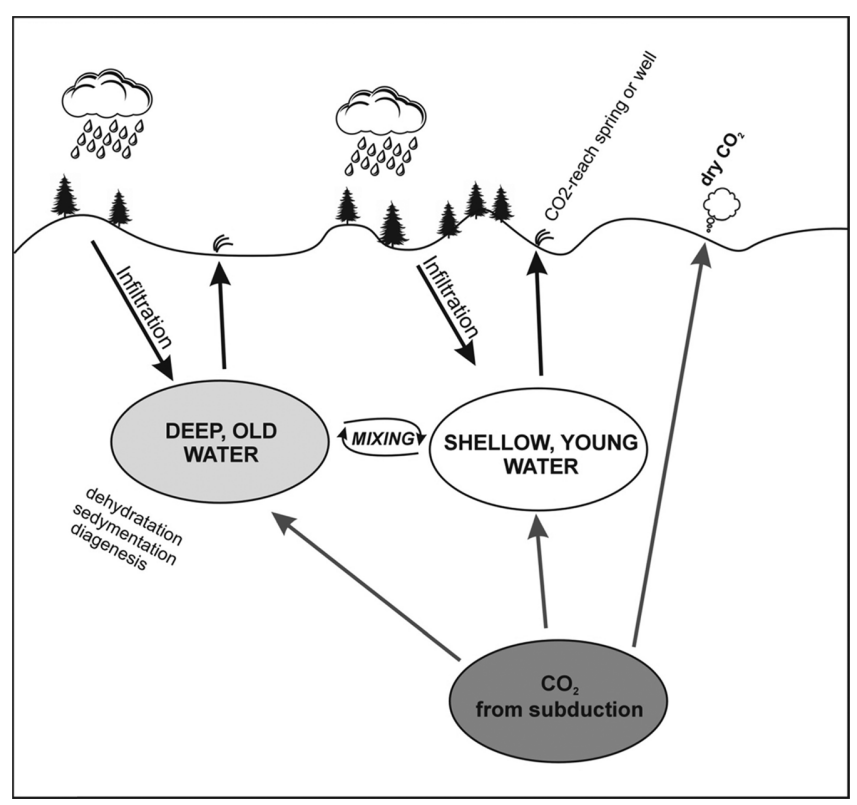

Figure 2. Model depicting the forming of carbon dioxide-rich waters in the Poprad Valley. 


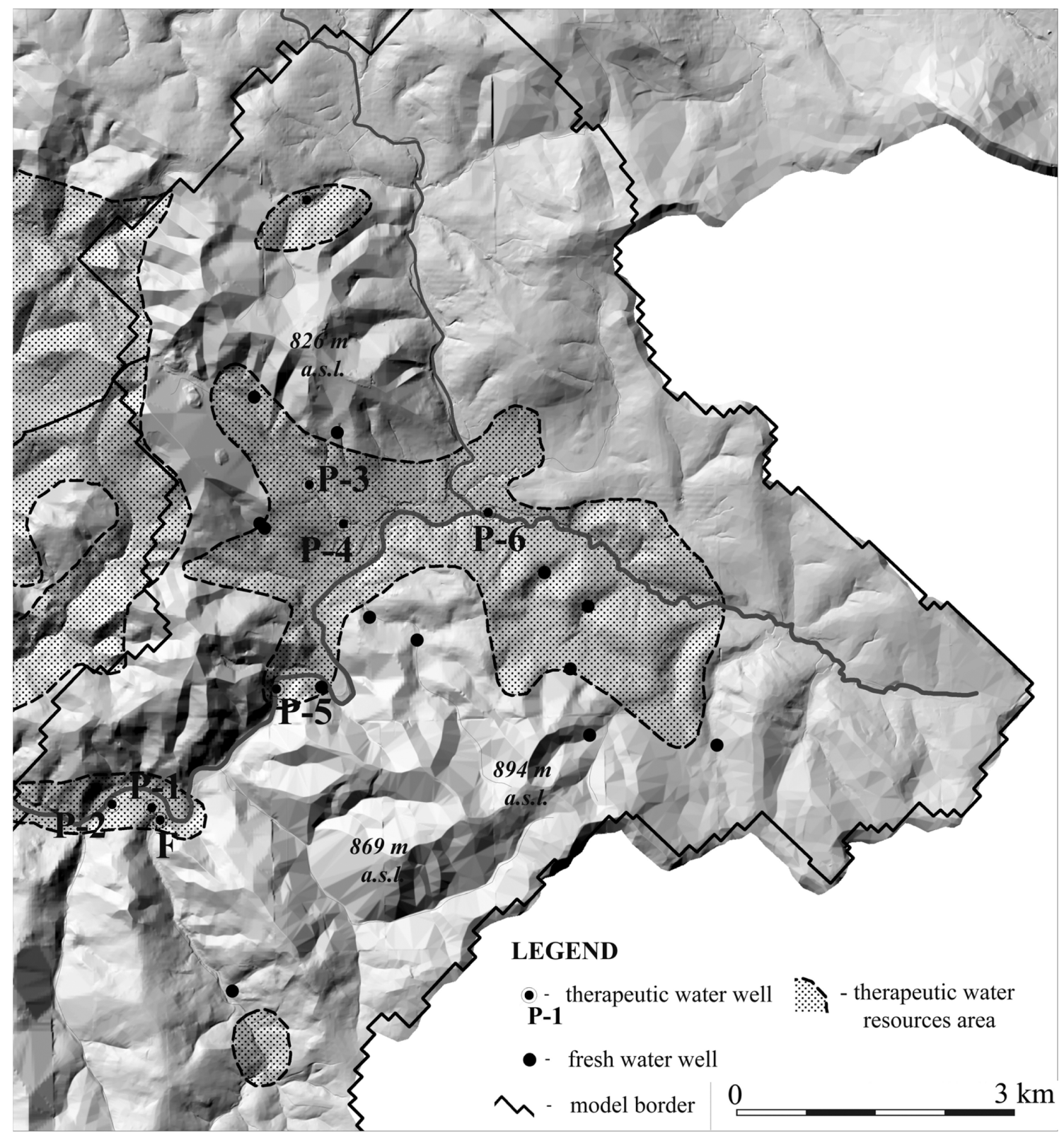

Figure 3. Location of well P-1.

For therapeutic waters, a safe yield was determined following the analyzes of $\mathrm{CO}_{2}$ exhalations, $\mathrm{CO}_{2}$ content in soil air and the occurrence of acidulous water springs, as well as the presence of well bores in which therapeutic waters were observed; it was found to cover 7.47 $\mathrm{km}^{2}$. This area of coexistence of fresh and therapeutic waters was first mapped out (Fig. 3) in 1996 (Poprawski et al., 1997) and modified in 2006 (Staśko et al., 2007).

\section{Methods}

\section{Hydrogeological Model Construction}

Hydrogeological model was constructed for steady-state conditions. The model was developed in Visual Modflow software, a wellverified tool, used for water balance studies (McDonald and Harbaugh,
1988). There was applied a discretization grid by dividing model area into 194 rows and 148 columns. Grid spacing was denser $(50 \mathrm{~m})$ in the region of wells locations and increases to $100 \mathrm{~m}$ in peripheral zones. The upper boundaries were established along the terrain surface.

There was constructed 7 numerical layers - each of constant thickness, in range 30-400 m, which reflected decreasing of hydraulic conductivity in flysh formation. The model bottom was applied $900 \mathrm{~m}$ b.t.s., to include the deepest groundwater intakes in model surrounding. The remaining boundaries were moved slightly beyond the border of the drainage basin in order to include all well influences. General-head boundary (GHB) was established for these borders. The recharge was set using a constant flux boundary condition, while the third-type reflected rivers and springs (Fig. 3).

The calibration process was conducted by trial-and-error method and was described in detail by Buczyński and Wcisło (2013). As a target for water tables, springs elevation was used as well as unused wells 


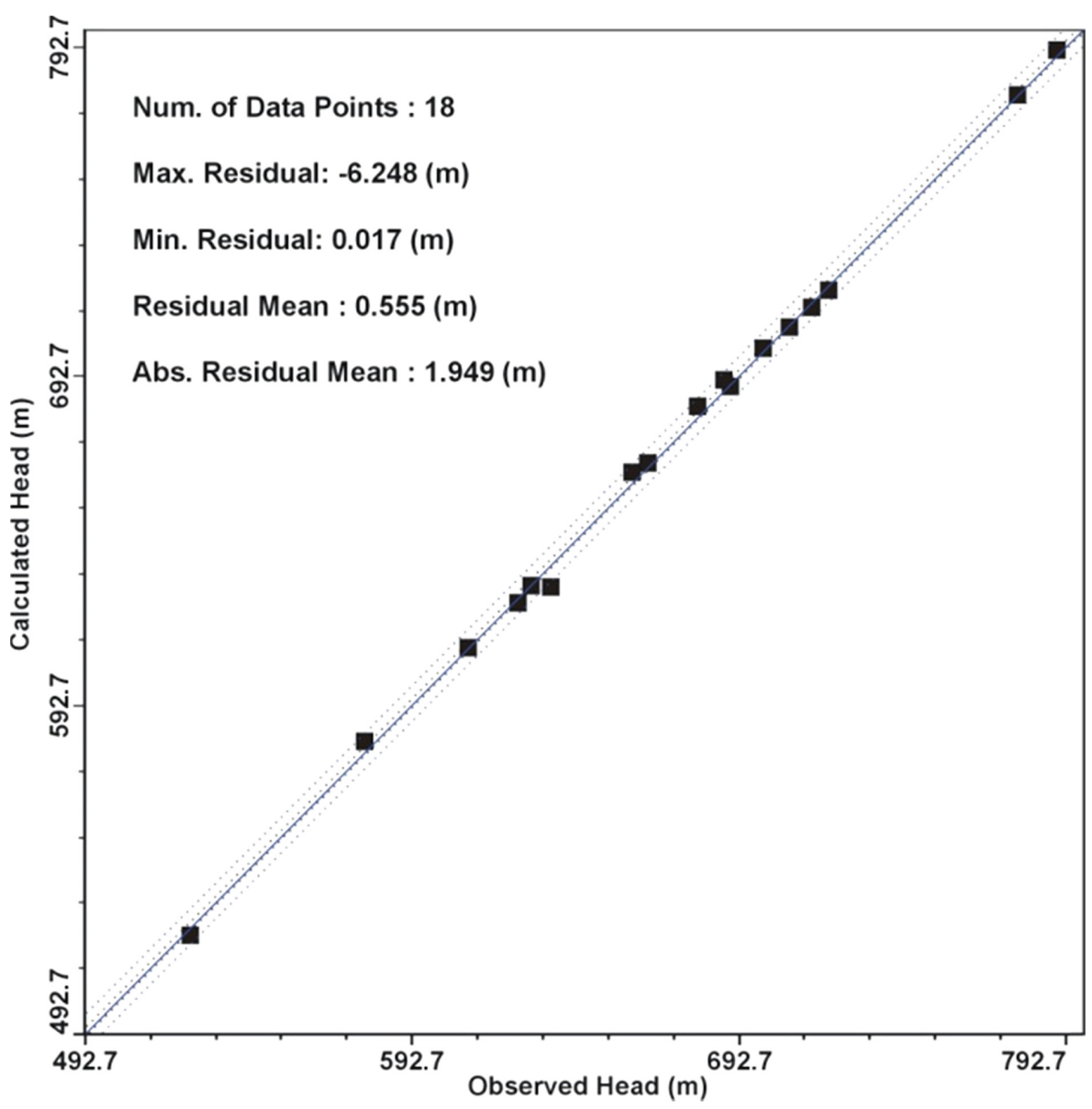

Figure 4. Observed vs. calculated hydraulic heads.

and calibration met the stated criteria (Fig. 4). Also for water budget, river fluxes corresponds in model and from field data (discrepancy $<5 \%$ ). As an outcome, the hydraulic conductivity distribution was obtained (Buczyński and Wcisło, 2013) as well as water table distribution (Fig. 5) and water budget (Table 1).

\section{Simulation of Mixing Processes}

According to previous research (Genesis and Occurrence of Therapeutic Waters), budget area for therapeutic water was applied to the model by creating zone budget in a 3 rd layer (Fig. 6). The fluxes from the 4th (old, deep water circulation) plus from sides (relatively young water from infiltration) can be treated as therapeutic water resources (as a mixing result).

In such scheme also can be investigated mixing process under influence of changing of therapeutic and fresh water abstraction. In the designated area, characterized by the coexistence of fresh and therapeutic waters, researchers carried out a local assessment of groundwater resources. Wellbore $\mathrm{P}-1$, whose average daily yield in 2016 equalled $\mathrm{Q}=9.9 \mathrm{~m}^{3}$, was chosen for this purpose, seeing as it demonstrated variations in mineralization in response to changes in withdrawal. The results were calculated in accordance with the created model. The area subject to the balancing lies in the rock mass at the depth of the bore, 100-200 m below ground level (Fig. 6).

Inflow from above and from the sides was identified as fresh water, while recharge from below (the fourth level of the model) was regarded as therapeutic water. Following the same methodology, an experiment was conducted in which a fictional freshwater well (F) was placed at a distance of approximately $250 \mathrm{~m}$ from well P-1 (a therapeutic water catchment). The effects of variations in the yield of well $F$ on the mixing ratio of the waters drawn in the P-1 wellbore were subsequently tested. Finally, the impact of changes in the exploitation of well P-1 on the waters' mixing ratio was also evaluated.

\section{Waters Mixing in Light of Correlation $\mathrm{HCO}_{3}$ and Conductivity}

Table 1. Water budget of modeled catchment in Tylicz region $\left(F=53.2 \mathbf{k m}^{2}\right)$

\begin{tabular}{cccccc}
\hline \hline IN & {$\left[\mathrm{m}^{3} / \mathrm{d}\right]$} & $\%$ & OUT & {$\left[\mathrm{m}^{3} / \mathrm{d}\right]$} & $\%$ \\
\hline Recharge & 27781.0 & 95.0 & River drainage & 27961.0 & 95.6 \\
River infiltration & 398.3 & 1.4 & Springs drainage & 634.7 & 2.2 \\
Inside & 1069.3 & 3.7 & Outside & 650.8 & 2.2 \\
Total & 29248.6 & 100.0 & Total & 29246.6 & 100.0 \\
Discrepancy & 2.1 & 0.0 & & \\
\hline
\end{tabular}

The mixing process involving deep waters (typically thermal, mineral or rich in carbon dioxide) can be studied using various methods which rely primarily on isotope analysis or chemical composition (Cartwright et al., 2002; Balderer et al., 2014), as well as hydrochemical modelling.

One of these methods involves analyzing general mineralization and the content of a correlated component in the water (Ovczynnikov, 1963). In the case of mineral waters occurring in the Tylicz region, the component demonstrating significant correlation is the bicarbonate ion (Fig. 7). Since the electrical conductivity of water is the most frequently tested parameter, the graph below illustrates its correlation with the $\mathrm{HCO}_{3}^{-}$ion content. Additionally, Table 2 presents variability statistic of conductivity.

Maximal noticed conductance (cond $=3,100 \mathrm{mS} / \mathrm{cm}$ ) was interpreted as $100 \%$ participation of therapeutic water. $100 \%$ of fresh water corresponds to cond $=448 \mathrm{mS} / \mathrm{cm}$ (average for fresh water from wells and springs in analyzed area).

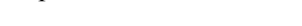




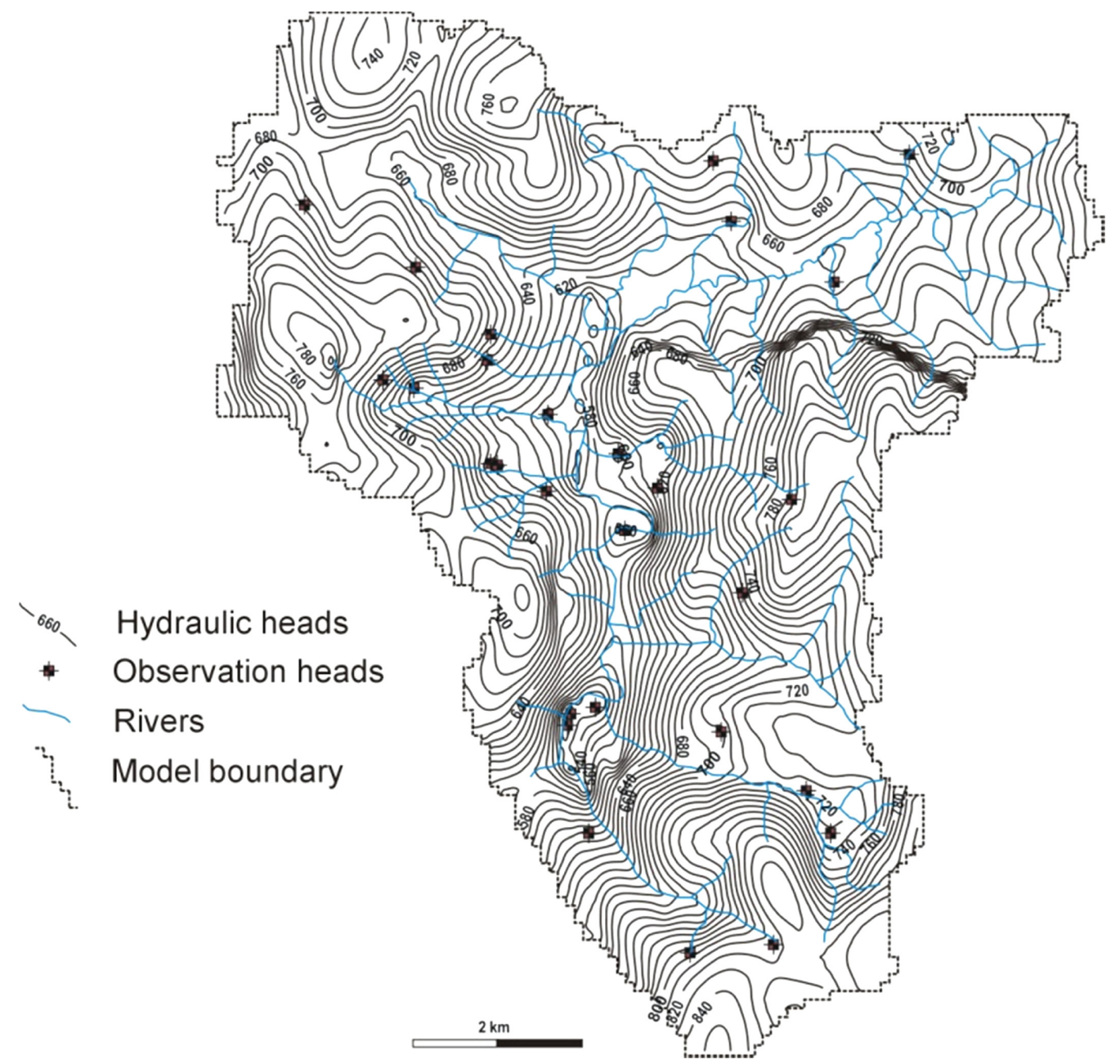

Figure 5. Water table contour map (model result, $2^{\text {nd }}$ layer).

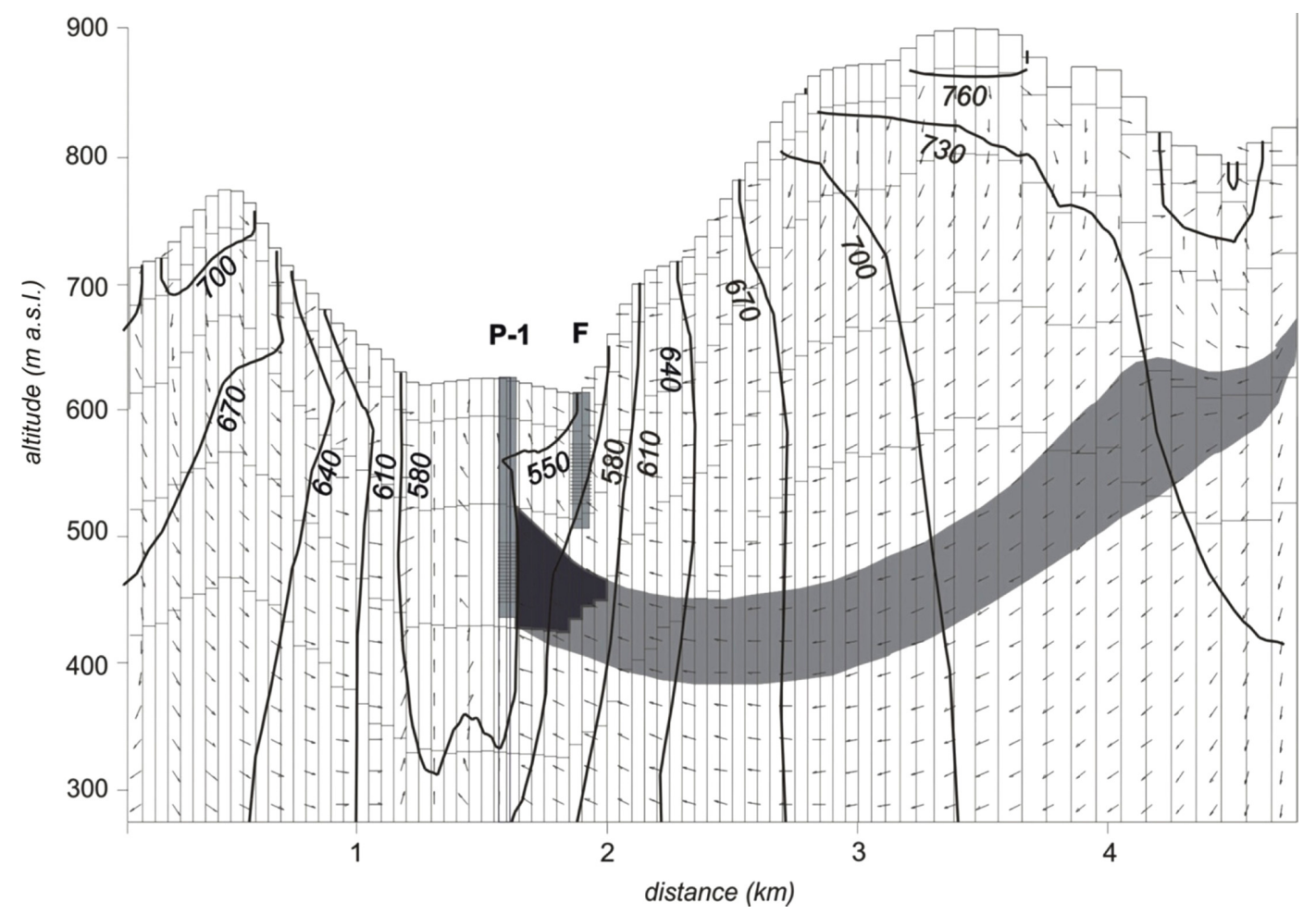

Figure 6. Cross-section of the balancing region of the P-1 wellbore inflow. The balancing area has been darkened. 
Table 2. Conductance variability in therapeutic water wells in Tylicz region in years 2006-2016

\begin{tabular}{cccccc}
\hline \hline \multirow{2}{*}{ Well name } & Number of analyzes & \multicolumn{2}{c}{ Conductance (mS/cm) } & \multicolumn{2}{c}{$\begin{array}{c}\text { Range of variability } \\
(\mathrm{mS} / \mathrm{cm})\end{array}$} \\
\cline { 3 - 5 } & & Min. & Max. & Avg. & 1.526 \\
P-2 & 1031 & 3.100 & 1.574 & 2.183 & 0.601 \\
P-1 & 887 & 1.191 & 0.590 & 0.940 & 0.795 \\
P-3 & 906 & 1.448 & 0.653 & 0.971 & 0.974 \\
mean & 941 & 1.913 & 0.939 & 1.365 & \\
\hline
\end{tabular}

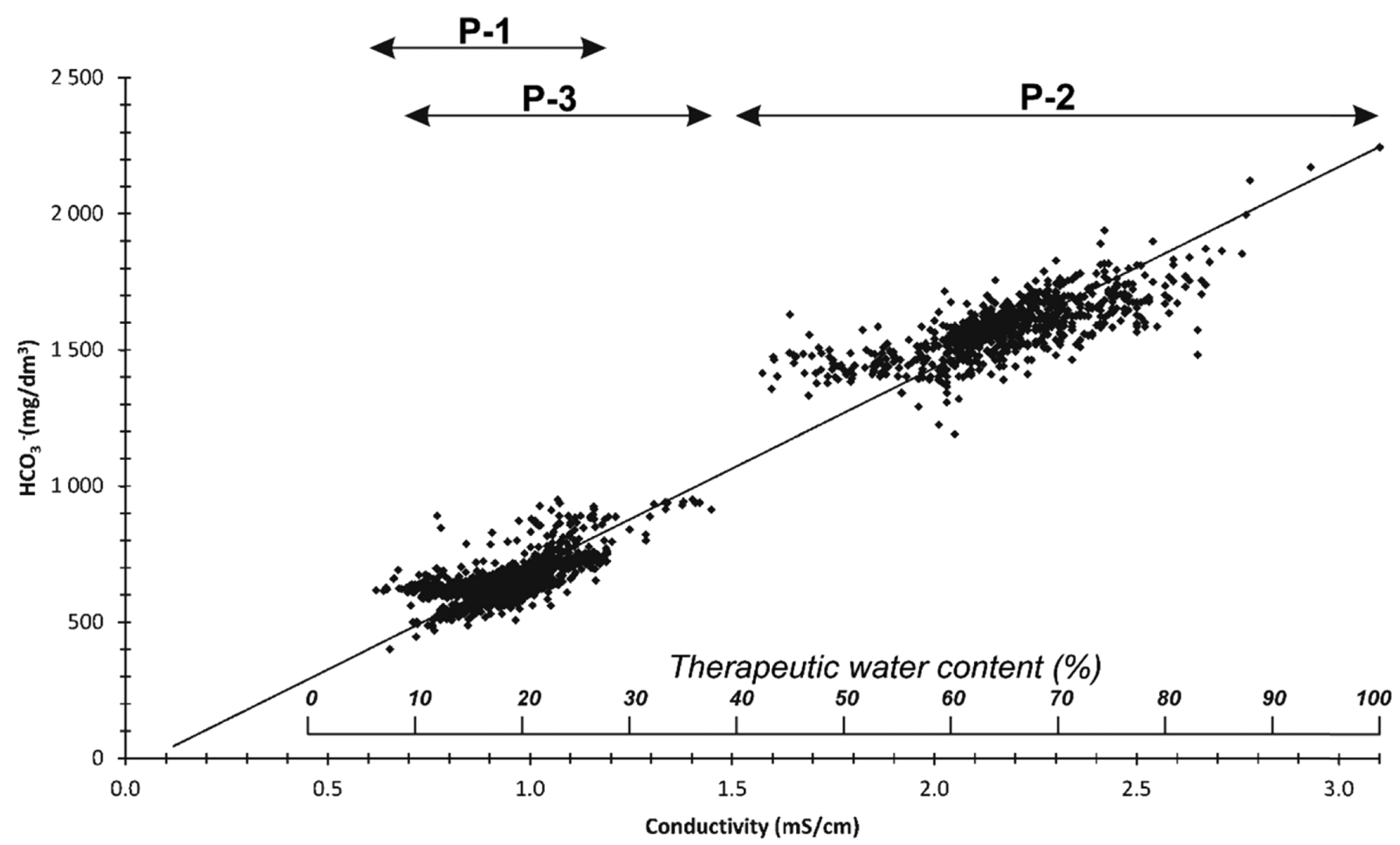

Figure 7. $\mathrm{HCO}_{3}^{-}$ion content vs conductivity (therapeutic water from Tylicz region).

\section{Results}

The goals of the modeling were to investigate i) therapeutic water resources in the model by expressing mixing process of entire model, ii) mixing process in local scale by balancing water fluxes to the capture zone and influencing of fresh and therapeutic water extracting.

\section{Regional Resources Assessment}

For regional (total) therapeutic water resources, the zone budged was used derived from previous research. In next step, fluxes to this zone from sides and from the bottom in 3rd model layer were calculated (100-200 m b.t.s.). Resulting outcome was:

$$
\mathrm{Q}=1.162 \mathrm{~m}^{3} / \mathrm{d}
$$

For the area of the $53.2 \mathrm{~km}^{2}$, (in this study) was obtained $18.44 \mathrm{~m}^{3} /$ $\left(\mathrm{d} \cdot \mathrm{km}^{2}\right)$ or $7 \mathrm{~mm} / \mathrm{a}$.

\section{Mixing in Capture Zone}

Investigation of ascending and side flow can be applied by water balance of capture zone for well P-1 (therapeutic water, $Q=9.9 \mathrm{~m}^{3} / \mathrm{d}$ in 2016 and $55 \mathrm{~m}^{3} / \mathrm{d}$ in 2006- the highest) in the model. Such balance equation was shown below on the graph (Fig. 9). Italic marked elements show the water balance for exploitation $\mathrm{Q}=55 \mathrm{~m}^{3} / \mathrm{d}$.

There was applied the approach, where mixing proportion is dependent on ascending part of water in comparison with side water flow into capture zone.

In case of actual discharge $\left(9.9 \mathrm{~m}^{3} / \mathrm{d}\right)$ - therapeutic water participation equals $14 /(14+47+0)=23 \%$, but in case of increased discharge $(55$ $\left.\mathrm{m}^{3} / \mathrm{d}\right)$, participation of therapeutic water is lower: $35 /(35+108+66)=$ $17 \%$. The differences are apparent. Increase of therapeutic water participation in 2016 is caused by reducing of fresh water inflow (from sides and top). The origin of observed phenomenon it's not only change of water discharge, but changing also the capture zone area for years 2006 and 2016.

In the second stage of investigation, in the capture zone of P-1, the virtual well was placed ( $\mathrm{F}$-fresh water only) and the water budget was analyzed once again (Fig. 10). As F-discharge $Q_{f}=90 \mathrm{~m}^{3} / \mathrm{d}$ (typical for the research area) was taken and for therapeutic water in $\mathrm{P}-1 \mathrm{Q}_{\mathrm{t}}=55 \mathrm{~m}^{3} / \mathrm{d}$ was applied (high value from 2006). Bold marked elements show the water balance for exploitation therapeutic and fresh water simultane- 


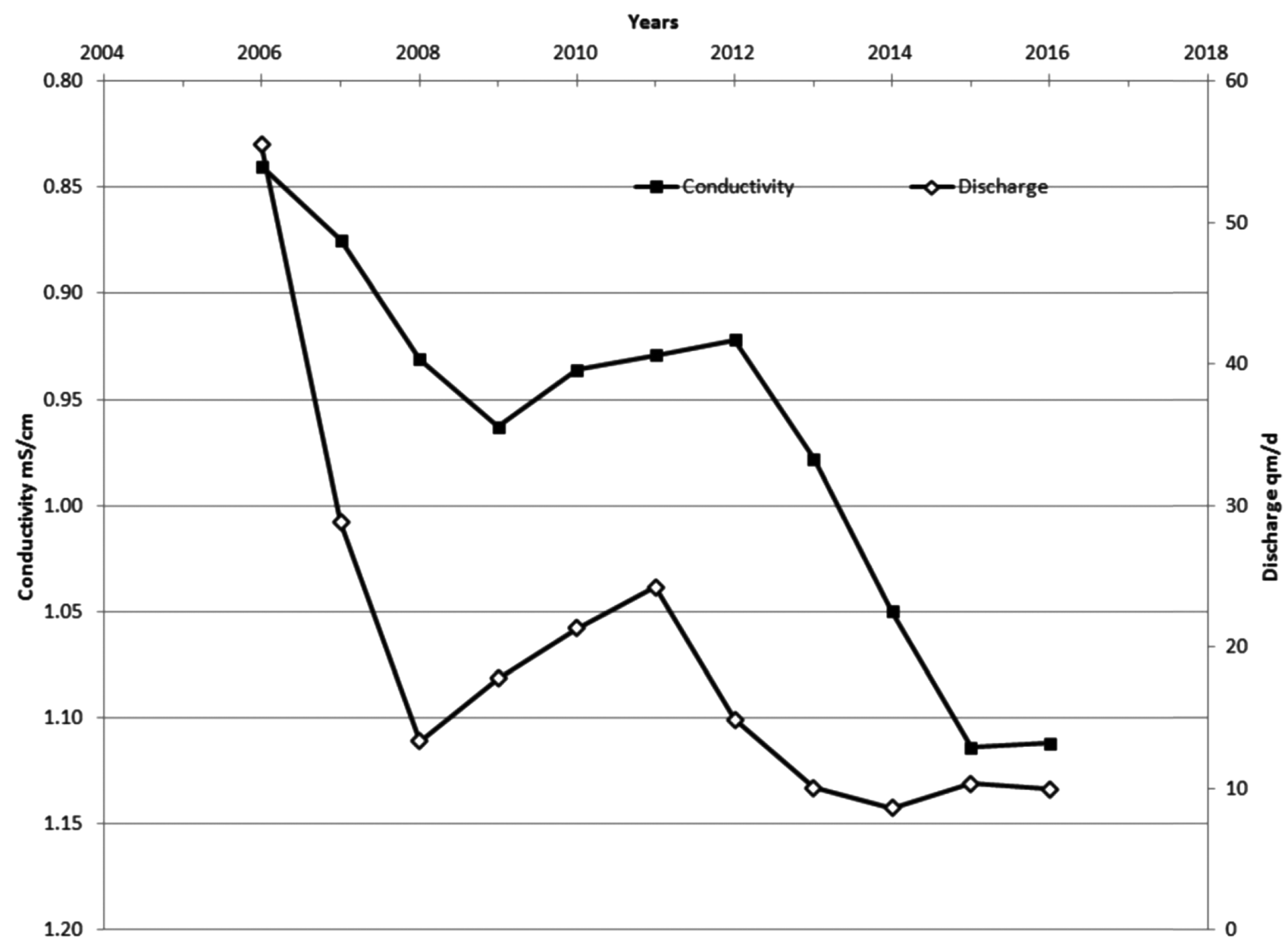

Figure 8. TDS and discharge graph in well P-1.

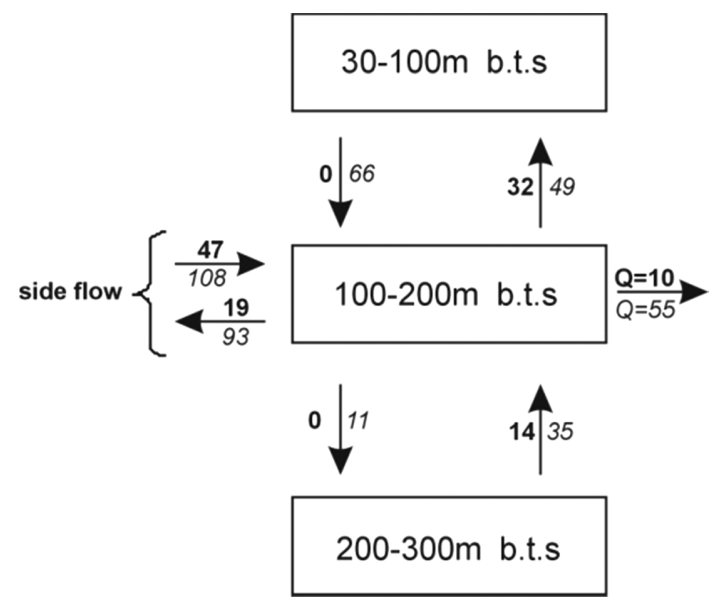

Figure 9. Budget of fresh and therapeutic water mixing in catchment area of well $P-1$ (therapeutic water discharge $10 \mathrm{~m}^{3} / \mathrm{d}$ and $55 \mathrm{~m}^{3} / \mathrm{d}$ ).

ously, italic - therapeutic water only.

As an outcome, the participation of therapeutic water was obtained: $37 /(37+107+66)=18 \%$.

The results are unequivocal - exploitation of fresh water by virtual well doesn't exert any influence on fresh/therapeutic water proportion, the difference in water budget with and without fresh water exploitation is minimal (about $1 \mathrm{~m}^{3} / \mathrm{d}$ ).

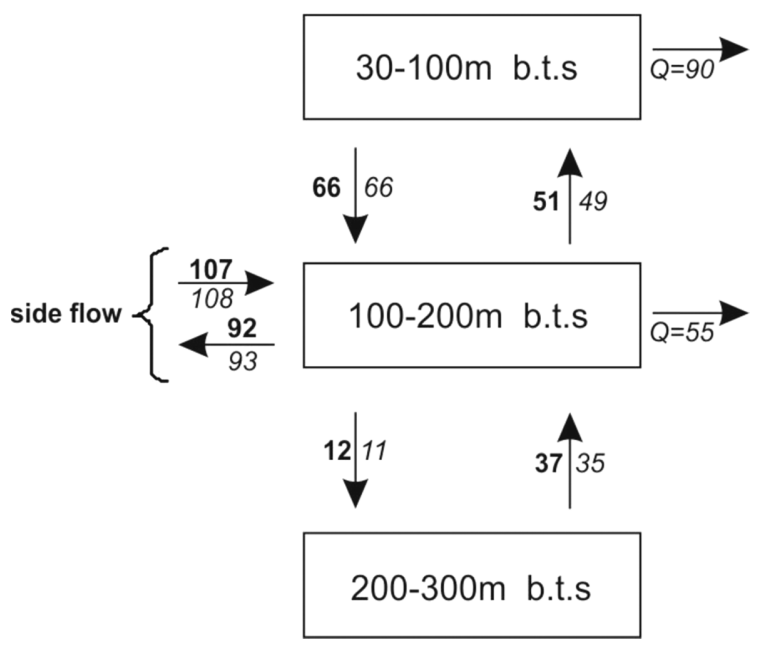

Figure 10. Budget of fresh and therapeutic water mixing in catchment area of well P-1 (therapeutic water discharge $55 \mathrm{~m}^{3} / d$ - italic and fresh water $90 \mathrm{~m}^{3} / d+$ therapeutic water $55 \mathrm{~m}^{3} / d$ - bold).

\section{Discussion}

The outcomes need to be discussed by comparison with another research in different scales and numerical model verification as a main method in this analysis. 


\section{Regional Resources Assessment of Therapeutic Water}

Therapeutic water occurrence in Polish catchment of Poprad river (Carpathians) was defined basing on it's direct observation (wells, springs) and $\mathrm{CO}_{2}$ content in soil. The therapeutic water resources were assessed by water budget analyzing on numerical model on the depth of 70$170 \mathrm{~m}$ b.t.s., by comparison of ascending- and side flows in the region of therapeutic water occurrence.

By analyzed catchment area of $483 \mathrm{~km}^{2}$, the therapeutic water was recognized on the $105.16 \mathrm{~km}^{2}$. The resources were estimated to $19,442.4$ $\mathrm{m}^{3} / \mathrm{d}$ (Koślacz et al., 2014). In this research area $\left(53.2 \mathrm{~km}^{2}\right)$, the therapeutic water occurs on the $7.47 \mathrm{~km}^{2}$ (Fig. 3) and resources equal to $1,162 \mathrm{~m}^{3} / \mathrm{d}$ (the modular value $0.25 \mathrm{dm}^{3} / \mathrm{s} \cdot \mathrm{km}^{2}$ ).

The modulus obtained in present study is lower than by Poprawski et al. (1997), Ciężkowski et al. (1999) and Koślacz et al. (2014), respectively: $0.33,0.37$ and $0.64 \mathrm{dm}^{3} / \mathrm{s} \cdot \mathrm{km}^{2}$.

In every case, comparison of water resources with allowed exploitation suggest there are significant reserve.

\section{Mixing of Therapeutic and Fresh Water in the Poprad Valley}

Water exploited by well P-1 shows cond=1.04 mS/cm (a 20162017) and is characterized by fluctuations and increase from 2006. The inverse correlation with mean-year discharge is clear (Fig. 8). Former research shows lower conductance before 2006 (Staśko et al., 2007).

In regional investigation (Staśko et al., 2007) conducted in years 2004-2007, hydrochemical model was implemented resulted in showing in well P-1 the proportion of therapeutic/fresh water $25 \% / 75 \%$.

Now, using extended analysis, for more wells and longer time (2006-2016), there were obtained a little different outcomes (Fig. 7) in 2016 (cond $=1.11 \mathrm{mS} / \mathrm{cm}$ ), the participation of therapeutic water is $24 \%$ and the 10 -years mean is $18 \%$ (cond $=0.94 \mathrm{mS} / \mathrm{cm}$ ). The model gave also $23 \%$ - the result remaining in high accordance, taking into account steady-state conditions. In this light, the results suggest, that conductance and mixing proportion should be stable in longer time if the same processes will influence on it. The final (long term) conductance for the discharge of $10 \mathrm{~m}^{3} / \mathrm{d}$ can be estimated to be $0.95-1.00$ $\mathrm{mS} / \mathrm{cm}$.

Total dissolved solids (TDS), same as conductance, as a parameters reflected mixing proportions, are significantly fluctuating in Tylicz region (Staśko et al., 2007). In years 1974-2006, the range of variability was $270-1,442 \mathrm{mg} / \mathrm{dm}^{3}$ (952 in average). Genesis of this changeability is not quite clear and need to be more detailed investigated. Present research seems to clarify some part of this case and gives promising results to build more complex tool.

In another region of Poprad Valley, Ciężkowski (2007) estimate the mixing proportions for $\mathrm{CO}_{2}-$ reach water on the basis $\mathrm{HCO}_{3}^{-}$content and TDS. High variability for individual wells is noted in ranges $70-0 \%$ and $38-17 \%$ of fresh water. For this fluctuation seem to be responsible changing in deep waters inflow or not stable contact with fresh water.

Kotowski and Operacz (2017) investigated discharge and chemistry for water in Poprad Valley (“Zubrzyk"). They also noted high variability in TDS in short- and long-time horizon and encounter difficulties with interpretation of this phenomenon.
Isotopic research (Porwisz et al., 1995) suggest differences in recharge structure in wells from Tylicz region. It depends on location and discharge. Max content of surface water was estimated to $69 \%$, in $1 / 3$ population of therapeutic water wells there wasn't any water from rivers content.

\section{Mixing Processes in the Light of Selected Research in the World}

There are many publications according to processes of water mixing of different genesis and content. Much often it is to be find the information about fact of mixing than the proportion of ingredients (Cartwright et al., 2002, Marques et al., 2001, Choi et al., 2014, Vinograd, 2004). There are many methods engaged, including: isotopic, mixing models, thermodynamic models, ion exchange and reaction paths.

Balderer et al. (2014) investigated 12 thermal spring in Budapest, basing on $\mathrm{Cl}$ and ${ }^{36} \mathrm{Cl}$ proportion and obtained various outcome, between 0 and $100 \%, 22 \%$ on average. They also include tritium analysis.

Renac et al. (2009) conducted research chemical composition of water from different depth in Central Massive (France), during boring 3 new wells (up to $500 \mathrm{~m}$ b.t.s.). The interpretation was conducted on mixing and thermodynamic model. Waters taken on 40-60 m b.t.s. included waters from $22 \mathrm{~m}$ b.t.s. $(60-70 \%)$ and deep - from $198 \mathrm{~m}$ b.t.s. (30-40\%). Water on the depth of 228 and $300 \mathrm{~m}$, included respectively: $16 \%$ and $23 \%$ "deep" waters (from referential $198 \mathrm{~m}$ depth). Analyzed water was characterized by temperatures between 15 and $26^{\circ} \mathrm{C}$. In France also Négrel et al. (1997) estimated participation of mineralized water in geothermal springs and streams on the basis of strontium isotopes proportion. The outcome was 10-30\%. While Haklidir (2013) applying method based on heat and silica solubility in geothermal reservoirs to mixing model, concluded that thermal deep-water in the South Marmara region (Turkey) derive in $70-80 \%$ from shallow, cold water.

The above research do not reflect time-dependent variability of the water proportions and bases on averaged values of isotopes or chemical components. In the light of mentioned research, present analysis indicates relatively simple - dynamic mixing model, correctly corresponding with another outcomes. It needs to be highlighted, that authors intention was to investigate exploitation influence on mixing process, which is clear on such model. The advantage of suggested method (in comparison to chemical and isotopic analysis) is possibility to generate prognosis, which show the steady-state (final) composition of water by known discharge. Steady-state hydrodynamical model allows also to face problems with high variability of chemical composition of water resulting from $\mathrm{HCO}_{3}$ content and TDS - the most important parameters of mineralized, drinking water.

\section{Conclusions}

There are many methods that offer an assessment of the proportion of water mixing. Most of them (e.g., hydrochemical and thermodynamic mixing models, chemical balance analyzes, isotopic analyzes) focus on the elaboration of genesis, the age of water and the sources of recharge. It is rarely possible to trace the variability of the mixing proportions of the therapeutic water components and forecast them. In 
the light of chemical and isotopic analysis, it is also more difficult to determine the impact of exploitation on the resources of therapeutic waters.

In such cases, in order to study the contribution of the mixing components of the water entering the P-1 well, additional results were provided by the groundwater mixing model (Modflow). It turned out that the increase in the level of therapeutic water exploitation from 9.9 to $55.5 \mathrm{~m}^{3} / \mathrm{d}$ contributes to the decrease in the participation of the deep component (from 27 to $17 \%$ ).

The model showed that the presence of a well capturing fresh water (fictitious well F) in the capture zone for the therapeutic water intake (P-1) does not affect the proportions of waters flowing into the well P-1. The test carried out with the F well capacity of $90 \mathrm{~m}^{3} / \mathrm{d}$ showed only a $1 \%$ increase in the participation of therapeutic waters in the well P-1.

The result obtained indicates that the exploitation of fresh water does not have to be forbidden in all areas of co-occurrence of therapeutic and fresh waters. In those areas, where no negative impact of freshwater exploitation on the parameters (quality and resources) of therapeutic waters has so far been found, with the objective of rational management of available water resources and in particular the protection of therapeutic waters, fresh water exploitation could be conditionally allowed. Such exploitation should be carried out "carefully", and the owner should be imposed restrictions and the obligation of continuous monitoring of characteristic components of therapeutic waters exploited both wells and natural springs. In the light of modeling results, such activities seem to be safe, but it should be remembered that none of the models reflects all processes that may be responsible for mixing water, such as changes in the flow paths pattern.

The research results suggest controlling up-to-date graph freshwater discharge vs therapeutic water parameters (e.g., TDS or $\mathrm{HCO}_{3}$ content). In the first stage (first week of exploitation) - every day, then every week (7-60 day of exploitation), then every month (60-365), then every year. If any negative correlation is observed, the test need to be stoped and fresh water well should be disabled. Adequate method should be practiced for exploitation therapeutic water - in this case controlling therapeutic water components vs discharge. If any correlation exists it is rational to hold discharge on relatively stable level.

\section{Acknowledgements}

The authors are truly thankful Mr. Tomasz Mateńko for his valuable substantive remarks and constructive help in data collecting Mr. Adam Zwolenik and Paweł Lupa. This research was founded by University of Wroclaw. Additionally, authors like to thank the reviewers and co-editor for their detailed comments, which were invaluable in the editing process. Suggestions made by the reviewers were very helpful in the process of eliminating errors and imperfections in the first version.

\section{References}

Balderer, W., Arno, H., Synal, A., Deak, J., Foris, I., and Leuenberger, F., 2014, Origin of thermal waters in Budapest based on chemical and isotope investigation including chlorine-36. In: Balderer, W., Porowski, A., Idris, H., and LaMoreaux, J.W. (Eds.), Environment Earth Science:
Thermal and Mineral Waters: Origin, Properties and Applications, pp. 49-60. DOI: 10.1007/978-3-642-28824-1_5.

Birkenmajer, K., 1986, Stages of structural evolution of the Pieniny Klippen Belt, Carpathians. Studia Geologica Polonica, v. 88, pp. 7-32.

Birkenmajer, K., and Dudziak, J., 1988, Age of Palaeogene flysch in the Pieniny Klippen Belt, Carpathians, Poland, based on calcareous nannoplankton. Bulletin of the Polish Academy of Sciences, Earth Sciences, v. 36(1), pp. 15-24.

Birkenmajer, K., and Oszczypko, N., 1989, Cretaceous and Palaeogene lithostratigraphic units of the Magura Nappe, Krynica Unit, Carpathians. Annales Societatis Geologorum Poloniae, v. 59, pp. 145-181.

Buczyński, S., Jakubiak, M., Modelska, M., and Wcisło M., 2015, Utrzymanie aparatury i ciągów pomiarowych na terenie zlewni rzeki górnej Muszynki - 2014 wraz z oceną współoddziaływania wód zwykłych i leczniczych w kontekście eksploatacji wód zwykłych w obszarze zasobowym wód leczniczych, CCHBC, Multivita, Tylicz, 49 p.

Buczyński, S., Modelska, M., and Wcisło W., 2017, Występowanie i reżim źródeł szczaw i wód kwasowęglowych w zlewni górnej Muszynki. Przegląd Geologiczny, v. 65(1), pp. 23-31.

Buczyński, S., and Wcisło, M., 2013, Predicting climate-induced changes in groundwater resources on the basis of hydrogeological model research: Case study of the Carpathian flysch belt). Episodes, v. 36(2), pp. 105-114. DOI: 10.18814/epiiugs/2013/v36i2/004

Cartwright, I., Weaver, T., Tweed, S., Ahearne, D., Cooper, M., Czapnik, K., and Trante, J., 2002, Stable isotope geochemistry of cold $\mathrm{CO}_{2}$ bearing mineral spring waters, Daylesford, Victoria, Australia: sources of gas and water and links with waning volcanism. Chemical Geology, v. 185, pp. 71-91. DOI: 10.1016/S0009-2541(01)00397-7

Chowaniec, J., 2006, Hydrogeologia Karpat, Przegląd Geologiczny, v. 54(10), pp. 846-847.

Ciężkowski, W. (ed.), 2007, Współoddziaływanie wód zwykłych i leczniczych - zasady dokumentowania, ochrony i gospodarki wodnej. Wydawnictwo Politechniki Wrocławskiej, Wrocław, 78 p.

Ciężkowski, W., Chowaniec, J., Górecki, W., Krawiec, A., Rajchel, L., and Zuber, A., 2010, Mineral and thermal waters of Poland. Przegląd Geologiczny, vol. 58(9/1), pp. 762-773.

Ciężkowski, W., Józefko, I., Schmalz, A., and Witczak, S., 1999, Dokumentacja hydrogeologiczna ustalająca zasoby eksploatacyjne wód leczniczych i dwutlenku węgla (jako kopaliny towarzyszącej) oraz ustalająca zasoby dyspozycyjne wód podziemnych (zwykłych oraz leczniczych i o właściwościach leczniczych) w zlewni Kryniczanki. Politechnika Wrocławska, 545 p.

Choi, B.Y., Yun, S.T., Kim, K.H., Choi, H.S., Chae, G.T., and Lee, P. K., 2014, Geochemical modeling of $\mathrm{CO}_{2}$-water-rock interactions for two different hydrochemical types of $\mathrm{CO}_{2}$-rich springs in Kangwon District, Korea. Journal of Geochemical Exploration, v. 144, pp. 49-62. DOI: https://doi.org/10.1016/j.gexplo.2014.02.009

Dowgiałło, J., and Paczyński, B., 2002, Podział regionalny wód leczniczych Polski. In: Paczyński B., (Ed.), Ocena zasobów dyspozycyjnych wód leczniczych i potencjalnie leczniczych: poradnik metodyczny, Państwowy Instytut Geologiczny, Warszawa, pp. 16-24.

Felter, A., Skrzypczyk, L., Socha, M., Sokołowski, J., Stożek, J., and Gryczko-Gostyńska, A., 2015, Mapa zagospodarowania wód podziemnych zaliczanych do kopalin w Polsce. PIG-PIB. Warszawa.

Hacquets B., 1796, Neueste physikalisch-politische Reisen in den Jahren 1794 und 95 durch die Dacischen und Sarmatischen oder Nordlichen Karpathen. Vierter Theil. Nürnberg, 256 p.

Haklidir, F.T., 2013, Hydrogeochemical evaluation of thermal, mineral and cold waters between Bursa city and Mount Uludağ in the South Marmara region of Turkey. Geothermics, v. 48, pp. 132-145. DOI: https://doi.org/10.1016/j.geothermics.2013.07.004

Jetel, J., 1986, Vertical variation in permeability of flysh rocks in the Czechoslovak Carpathians. Kwartalnik Geologiczny, v. 29(1), pp. 167-178.

Kania, J., Józefko, I., and Witczak, S. 2009, Metodyka oceny zasobów 
dyspozycyjnych wód leczniczych rejonu Muszyny na podstawie modelowania w systemie ArcGis i GMS. Biuletyn PIG, v. 436, pp. 205-214.

Koślacz, R., Buczyński, S., Wcisło, M., Koziołek, J., Modelska, M., Koślacz, M., Robak, A., and Domańska, U., 2014, Dokumentacja hydrogeologiczna ustalająca zasoby dyspozycyjne wód podziemnych w obszarach bilansowych współwystępujących wód leczniczych i zwykłych wód podziemnych w wydzielonym rejonie Karpat - zlewnia Popradu. Ministerstwo Środowiska, Departament Geologii i Koncesji Geologicznych, Warszawa, 199 p.

Kotowski, T., and Operacz, A., 2017, Zmienność parametrów eksploatacyjnych i fizykochemicznych wód leczniczych ujęcia Zubrzyk w warunkach współoddziaływania otworów. Przegląd Geologiczny, v. 65, pp. 983-988.

Krawczyk, J., 2010a, Dokumentacja hydrogeologiczna ustalająca zasoby eksploatacyjne ujęć wód podziemnych niebędących kopalinami (otwór W-2). Śląskie Towarzystwo Wiertnicze DALBIS, Radzionków, 45 p.

Krawczyk, J., 2010b, Dokumentacja hydrogeologiczna ustalająca zasoby eksploatacyjne ujęć wód podziemnych niebędących kopalinami/otwory W-3, W-4, W-5/ w miejsc. Wojkowa. Śląskie Towarzystwo Wiertnicze DALBIS, Radzionków, 60 p.

Marques, J.M., Monteiro, Santos F.A., Graça, R.C., Castro, R., Aires-Barros, L., Mendes, and Victor, L.A., 2001, A geochemical and geophysical approach to derive a conceptual circulation model of $\mathrm{CO}_{2}$-rich mineral waters: A case study of Vilarelho da Raia, northern Portugal. Hydrogeology Journal, v. 9, pp. 584-596. DOI: https://doi.org/10.1007/s10040001-0162-8

McDonald, M.G., and Harbaugh, A.W., 1988, A modular three-dimensional finite-difference groundwater flow model: USGS Technical Report on Modelling Techniques Book 6, USGS, Reston, 586 p. DOI: https://doi.org/10.3133/twri06A1

Nałęcki, P., Resko, D., Schmalz, A., and Witczak, S., 2004, Charakterystyka parametrów hydrogeologicznych szczelinowo-porowego złoża wód leczniczych w Krynicy. Biuletyn PIG, v. 404, pp. 145-164.

Négrel, P., Fouillac, C., and Brach, M., 1997, A strontium isotopic study of mineral and surface waters from the Cezallier (Massif Central, France): implications for mixing processes in areas of disseminated emergences of mineral waters. Chemical Geology, v. 135, pp. 89-101. DOI: https://doi.org/10.1016/S0009-2541(96)00110-6

Nowicki, Z., and Felter, A., 2013, Zmienność składu izotopowego wód podziemnych rejonu Krynicy-Zdroju i Muszyny w warunkach ich eksploatacji. Biuletyn PIG, v. 456, pp. 431-436.

Oszczypko, N., 1991, Stratigraphy of the Palaegene Deposits of the Bystrica unit (Magura Nappe, Polish Outer Carpathians). Biul. Pol. Acad. Sc., Earth Scs., v. 39 (4), pp. 433-445.

Oszczypko, N., 1998, The Western Carpathian Foredeep development of the foreland basin in front of the accretionary wedge and its burial history (Poland). Geologica Carpathica, v. 49, (6), pp. 415-431.

Oszczypko, N., Malata, E., Oszczypko-Clowes, M., and Duńczyk, L., 1999, Budowa geologiczna Krynicy (płaszczowina magurska). Przegląd Geologiczny, v. 47, pp. 549-559.

Ovczynnikow A.M., 1963, Mineralnyje vody, Gasgeołtehizdat, Moskwa.

Paczyński, B., 1995, Atlas hydrogeologiczny Polski 1:500 000 - Zasoby, jakość i ochrona zwykłych wód podziemnych., Państwowy Instytut Geologiczny, Warszawa.

Poprawski, L., Biniak, G., Gurwin, J., Jasiak, T., Kowalczyk, A., Krzempek, J., Kus, S., Limisiewicz, P., Marszałek, H., Napierała, K., Olszewski, W., Wąsik, M., and Cisek, J., 1997, Dokumentacja zasobów dyspozycyjnych i eksploatacyjnych wód podziemnych (zwykłych i leczniczych) na obszarze gmin uzdrowiskowych Krynica, Muszyna i Piwniczna. PPUH "Hydrogeo" Ltd. Wrocław, 268 p.

Porwisz, B., Zuber, A., Węcławik, S., Cisek, J., Kowalski, J., and Mądry, J., 1995, Określenie obszarów alimentacji złóż wód podziemnych (zwykłych, mineralnych i leczniczych) eksploatowanych otworami studziennymi przez Zakład Produkcji Wód Mineralnych "Multico" Krynica-Tylicz. HYDRECOL, Kraków, 141 p.
Rajchel, L., 2012, Szczawy i wody kwasowęglowe Karpat Polskich, Wydawnictwa AGH, Kraków, 194 p.

Renac, C., Gal, Fr., Ménot, R-P., Squarcioni, P., and Perrache, Ch., 2009, Mean recharge times and chemical modelling transfers from shallow groundwater to mineralized thermal waters at Montrond-les-Bains, Eastern Massif Central, France. Journal of Hydrology, v. 376, pp.1-15. DOI: 10.1016/j.jhydrol.2009.07.011

Staśko, S., Buczyński, S., Ciężkowski, W., Oszczypko, N., Modelska, M., Olichwer, T., Tarka, R., and Wcisło, M., 2007, Dokumentacja hydrogeologiczna w celu ustalenia zasobów zwykłych i mineralnych wód podziemnych dla górnej zlewni Muszynki. Uniwersytet Wrocławski, Wrocław, $274 \mathrm{p}$.

Staśko, S., and Modelska, M., 2016, Interaction between fresh and therapeutic groundwater in exploitation conditions based on the one year $\mathrm{H}$, $\mathrm{O}$, and $\mathrm{S}$ isotope and chemical observations (Carpathians, SW Poland). 43rd IAH Congress: Groundwater and society: 60 years of IAH, 2016, Montpellier, France, Abstract, p. 530

Szczepański, A., and Szklarczyk, T., 2005, Zagrożenia w gospodarowaniu zasobami wód leczniczych na przykładzie rejonu Krynicy i Muszyny. Współczesne Problemy Hydrogeologii, v. XII, pp. 696-700.

Witczak, S., Duńczyk, L., Motyka, J., and Oszczypko, N., 2002, Regionalny wielowarstwowy model pola hydrodynamicznego w utworach fliszu karpackiego na przykładzie zlewni kryniczanki (płaszczowina magurska). Biuletyn PIG, v. 404, pp. 263-290.

Vinograd, N. A., 2004, Formation of mineral and thermal waters of some artesian basins in Russia. Environmental Geology, v. 46, pp. 675-679. DOI: $10.1007 / \mathrm{s} 00254-004-1007-2$

Zejszner, L., 1836, O wodach kwaśnych, czyli szczawach w Karpatach. Pam. Farmac. Krak., III. Wyd. Flor. Sawiczewskiego, Kraków, pp. 265-298.

Zuber, A., and Chowaniec, J., 2009, Diagenetic and other highly mineralized waters in the Polish Carpathians. Applied Geochemistry, v. 24, pp. 1889-1900. DOI: https://doi.org/10.1016/j.apgeochem.2009.07.002

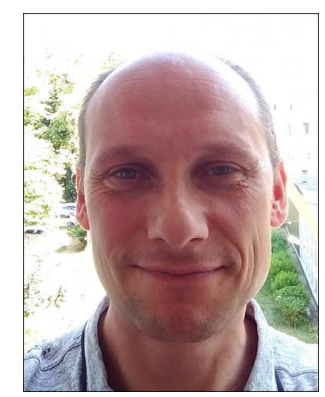

Marek Wcisto is an assistant professor at the Univesrsity of Wroclaw. He joined the Department of Hydrogeology in 2008 and completed a Ph.D. thesis concerning modelling of small basins in Sudety area in 2009. His research is focused on modelling of groundwater flow and mass transport. He also participates in regional projects connected to groundwater resources among others in Polish Carpathians. Last large research, which he realized was regional groundwater model of KGHM impact on groundwater bodies.

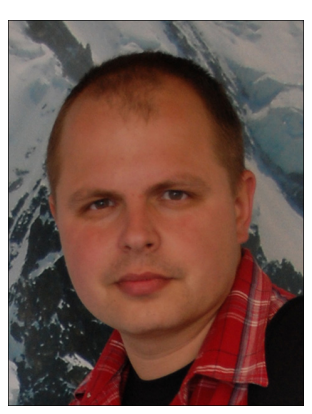

Sebastian Buczyński, Ph.D., is a hydrogeologist at the Faculty of Earth Sciences and Environmental Management, University of Wrocław. His main research area including hydrology of springs and the hydrogeology of heterogeneous rocks - hard rocks, flysh and karst formations. During the last four years the research has been concentrated to the groundwater resources especially groundwater flow systems and the conditions of the formation of groundwater resources in crystalline and sedimentary rocks. 